\title{
Biomarkers of ketosis in dairy cows at postparturient period: acute phase proteins and pro-inflammatory cytokines
}

\author{
Wael M. El-Deeb ${ }^{1,2}$, and Sabry M. El-Bahr ${ }^{3,4 *}$ \\ ${ }^{I}$ Department of Clinical Studies, College of Veterinary Medicine, King Faisal University, Al-Ahsa, Saudi \\ Arabia \\ ${ }^{2}$ Department of Veterinary Medicine, Infectious Diseases and Fish Diseases, Faculty of Veterinary Medicine, \\ Mansoura University, Mansoura, Egypt \\ ${ }^{3}$ Department of Physiology, Biochemistry and Pharmacology (Biochemistry), College of Veterinary Medicine, \\ King Faisal University, Al-Ahsa, Saudi Arabia \\ ${ }^{4}$ Department of Biochemistry, Faculty of Veterinary Medicine, Alexandria University, Egypt
}

EL-DEEB, W. M., S. M. EL-BAHR: Biomarkers of ketosis in dairy cows at postparturient period: acute phase proteins and pro-inflammatory cytokines. Vet. arhiv 87, 431-440, 2017.

\section{ABSTRACT}

Searching for new or additional biomarkers is an essential step toward the control of metabolic diseases such as ketosis. Acute phase proteins (APP) and pro-inflammatory cytokines were used successfully as prognostic and diagnostic biomarkers for many animal diseases. However, their use in the diagnosis of ketosis in dairy cows in the postparturient period has not been completely elucidated. Therefore, 25 cows suffering from ketosis in the postparturient period were used in the current study, together with 20 healthy cows who served as a control. Blood samples were collected from both diseased and healthy animals, and the harvested serum was used for determination of APP and proinflammatory cytokines. The obtained results indicated that there was a significant $(\mathrm{P} \leq 0.05)$ increase in the levels of $\beta$-Hydroxybutyrate (BHBA), non-esterified fatty acids (NEFA), APP, namely: haptoglobin (HP), Serum Amyloid A (SAA), Fibrinogen (Fb), ceruloplasmin (Cp), $\alpha 1$ acid glycoprotein ( $\alpha 1-\mathrm{AG})$, and proinflammatory cytokines, namely:, interleukins IL-1 $\beta$, IL-6, IL-8, IL-12), Tumor necrosis factor-alpha (TNF- $\alpha$ ), interferon gamma (IFN- $\gamma$ ) in dairy cows affected with ketosis compared to the control. A positive correlation was observed among traditional biomarkers (BHBA, NEFA) and suggested biomarkers (APP and cytokines) in cows affected with ketosis. Conclusively, APP and pro-inflammatory cytokines could be used as promising biomarkers for ketosis in dairy cows in the postparturient period.

Key words: cows, ketosis, haptoglobin, fibrinogen, serum amyloid A, cytokines

\footnotetext{
*Corresponding author:

Prof. Dr. Sabry M. El-Bahr (BVSc, MVSc, PhD); Department of Physiology, Biochemistry and Pharmacology (Biochemistry), College of Veterinary Medicine, King Faisal University, Al-Ahsa, P.O. Box 400, Al-Hufof-31982, Saudi Arabia, Phone: +96 65 5890 7894; E-mail: sabryelbahr@hotmail.com
} 
W. M. El-Deeb and S. M. El-Bahr: Novel biomarkers of ketosis in postparturient cows

\section{Introduction}

The transition (periparturient) period in dairy cows is an unfavorable time for dairy farmers due to the high animal culling rate and reduction of milk yield (GOFF and HORST, 1997; JORRITSMA et al., 2001). In general, it represents 3 weeks before and after parturition (CONTRERAS and SORDILLO, 2011). Ketosis and mastitis are the most metabolic and infectious diseases of this period, respectively (JONSSON et al., 2013). The occurrence of ketosis in cows in the postparturient phase is attributed to the maximum stimulus for milk production and the low available glucose to the mammary glands for this task, whereby a negative energy balance is created. As a result of the negative energy balance, lipolysis occurs, the non-esterified fatty acids (NEFA) concentration increases and $\beta$-Hydroxybutyrate (BHBA) produced (MELENDEZ et al., 2009; DRACKLEY et al., 2005). Therefore $\beta$-Hydroxybutyrate (BHBA) is the most common biomarker for evaluation of ketosis and lipid mobilization (GONZALEZ et al., 2011). Higher concentrations of non-esterified fatty acids (NEFA) induces inflammation in humans (ZHANG et al., 2006; YAQOOB and CALDER, 2007) and animals (DYK et al., 1995; SORDILLO et al., 2009) with the subsequent release of proinflammatory cytokines (interleukins, TNF- $\alpha$, IFN- $\gamma$; KUSHIBIKI, 2011) from macrophages (KOJ, 1998) and other tissues, particularly the liver (BERTONI and TREVISI, 2013). These cytokines act as biomarkers of postpartum reproductive disorders (ISHIKAWA et al., 2004; ISLAM et al., 2013a; ISLAM et al., 2013b). Plasma interleukins (IL-1 $\beta$ and IL-6) were positively correlated with the severity of the inflammation, worse health status and low milk production in the early lactation period (TREVISI et al., 2012; TREVISI et al., 2015). Proinflammatory cytokines mediate the effect of APP (Hp, Fb, SAA; GRUYS et al., 2005). Acute phase proteins (APP) are a positive (upregulated; $\mathrm{Hp}, \mathrm{Fb}, \mathrm{SAA}$, ceruoloplasmin and $\alpha 1$-acid glycoprotein) or negative (downregulated; albumin, transferring and $\alpha$-fetoproteins) response to stressful situations (LOUGHMILLER et al., 2007; GABAY and KUSHNER, 1999). Acute phase proteins (APP) and proinflammatory cytokines have been presented as prognostic and diagnostic biomarkers for many animal diseases by our team (EL-DEEB and EL-BAHR, 2010; EL-BAHR and EL-DEEB, 2013; EL-DEEB et al., 2014; EL-DEEB and EL-BAHR 2014a; EL-DEEB and ELBAHR, 2014b). However, the investigation of these vital biomarkers in dairy cows in the peripaturient period has not been completely elucidated yet. Therefore, the current study aimed to evaluate the diagnostic potentials of acute phase proteins and proinflammatory cytokines, as biomarkers of ketosis in dairy cows during the peripaturient period.

\section{Material and methods}

Animals. This study was carried out on a total number of 45 cows (3-9 weeks post parturient), aging from 4 to 7 years old, with average body weight of $650 \pm 15 \mathrm{~kg}$ from a private farm. The selected cows were assigned to two groups: the first group represented control cows $(n=20)$, whereas the second group $(n=25)$ consisted of ketotic cows. All 
the cows were clinically examined every day until 4 weeks after parturition (RADOSTITS et al., 2007).

Detection of ketonuria. The presence of ketone bodies in the urine was detected by commercial kits (Fujisawa pharmaceutical Co., Osaka, Japan).

Samples collection. Blood samples were collected from the jugular vein of both groups into plain and sodium citrate vacutainers (sodium citrate 3.8\%). Plasma was used for measurement of fibrinogen. Sera were harvested and stored frozen at $-20{ }^{\circ} \mathrm{C}$ until assayed for non-esterified fatty acids (NEFA), $\beta$-Hydroxybutyrate (BHBA), haptoglobin (HP), serum amyloid A (SAA), fibrinogen (Fb), interleukins (IL-1 $\beta$, IL-6, IL-8, IL-12), interferon $-\gamma(\mathrm{IF}-\gamma)$, and tumor necrosis factor $-\alpha(\mathrm{TNF}-\alpha)$.

Biochemical analysis. Serum concentrations of NEFA were found using commercially available test kits supplied by Randox laboratories Ltd, Crumlin Co., Antrim, UK. Uric acid was determined by the uricase-POD enzymatic colorimetric method, using kits provided by Spinreact, Spain. Serum concentrations of BHBA were determined by the kinetic enzymatic method, using a commercially available kit (Ranbut D-3- hydroxybutyrate, Randox laboratories Ltd, Crumlin Co., Antrim, UK). The assay was based on the reversible reaction between 3-hydroxybutyrate and NAD1, catalyzed by 3-hydroxybutyrate dehydrogenase, and the change in NADH concentration was measured by changes in the absorbance at $340 \mathrm{~nm}$. Serum Hp was measured spectrophotometrically with a commercially available colorimetric kit (Phase HP kit, Tridelta Ltd., Ireland), according to the manufacturer's instructions. Serum SAA was measured with a commercially available ELISA kit (Phase SAA kit, Tridelta Ltd., Ireland), according to the manufacturer's instructions. Fibrinogen concentrations in the plasma were measured with a commercial ELISA kit (USCN, Life Science, USA) according to the manufacturer's instructions. Ceruoloplasmin activity was measured using a commercial kit (MyBiosource, USA). Serum $\alpha 1$-acid glycoprotein was analyzed using a commercial radial immunodiffusion kit manufactured by Ecos Institute (Furukawa, Miyagi, Japan). Interleukins (IL-1 $\beta$, IL-6, IL-8, IL-12), tumor necrosis alpha (TNF- $\alpha$ ), and interferon gamma (IFN- $\gamma$ ) levels were determined from undiluted serum samples, using a commercially available ELISA Kits (Biosource International, California, USA). The plates were read at $450 \mathrm{~nm}$ on a computerized automated micro plate ELISA reader (Bio TEC, ELX800G, USA). All measurements were made in duplicate.

Statistical analysis. All data were presented as mean \pm standard error of mean using one way analysis of variance (ANOVA). All tests were performed using the computer package of the statistical analysis system (SAS, 2002). 
W. M. El-Deeb and S. M. El-Bahr: Novel biomarkers of ketosis in postparturient cows

\section{Results}

Clinical examination. The diseased cows showed Anorexia, ruminal stasis, constipation and significant reduction in milk yield.

Biochemical analysis of NEFA, BHBA and acute phase proteins. The concentrations of acute phase proteins are shown in Table 1 . The presented data indicate a significant increase in the levels of $\beta$-Hydroxybutyrate (BHBA), non-esterified fatty acids (NEFA), haptoglobin (Hp), serum amyloid A (SAA), fibrinogen $(\mathrm{Fb})$, ceruoloplasmin and $\alpha 1$-acid glycoprotein in cows affected with ketosis compared to the control.

Table 1. Acute phase proteins in serum of control and cows affected with ketosis

\begin{tabular}{|l|c|c|}
\hline Variables & Ketosis & Control \\
\hline NEFA $(\mathrm{mg} / \mathrm{dL})$ & $623.32 \pm 9.32^{*}$ & $365.32 \pm 11.2$ \\
\hline BHBA $(\mathrm{mmol} / \mathrm{L})$ & $1.9 \pm 0.023^{*}$ & $0.6 \pm 0.01$ \\
\hline $\mathrm{HP}(\mathrm{g} / \mathrm{L})$ & $1.7 \pm 0.12^{*}$ & $0.1 \pm 0.01$ \\
\hline $\mathrm{SAA}(\mathrm{mg} / \mathrm{L})$ & $46.32 \pm 1.23^{*}$ & $23.9 \pm 0.56$ \\
\hline$\alpha 1$ Acid glycoprotein $(\mathrm{g} / \mathrm{L})$ & $2.32 \pm 0.23^{*}$ & $1.1 \pm 0.44$ \\
\hline Ceruloplasmin $(\mathrm{g} / \mathrm{L})$ & $0.72 \pm 0.12^{*}$ & $0.24 \pm 0.36$ \\
\hline Fibrinogen $(\mathrm{g} / \mathrm{L})$ & $1.76 \pm 0.53$ & $1.58 \pm 2.94$ \\
\hline
\end{tabular}

Values are expressed as mean $\pm \mathrm{SEM}$; *Means are significantly different at the level $(\mathrm{P} \leq 0.05)$

Biochemical analysis of proinflammatory cytokines. The values of proinflammatory cytokines are presented in Table 2 . The data summarized in this table revealed significant elevations in the levels of interleukins (IL-1 $\alpha$, IL-1 $\beta$, IL-6, IL-8, IL-12), tumor necrosis factor alpha (TNF- $\alpha$ ) and interferon gamma (IFN- $\gamma$ ) in dairy cows affected with ketosis compared to the control.

Table 2. Proinflammatory cytokines in serum of control and cows affected with ketosis

\begin{tabular}{|l|c|c|}
\hline Variables & Ketosis & Control \\
\hline IF- $\gamma(\mathrm{pg} / \mathrm{mL})$ & $44.76 \pm 2.56^{*}$ & $22.32 \pm 2.36$ \\
\hline $\mathrm{IL}-1 \beta(\mathrm{pg} / \mathrm{mL})$ & $168.3 \pm 2.36^{*}$ & $102.43 \pm 2.45$ \\
\hline $\mathrm{IL}-6(\mathrm{ng} / \mathrm{mL})$ & $12.23 \pm 1.33^{*}$ & $5.92 \pm 0.65$ \\
\hline $\mathrm{IL}-12(\mathrm{ng} / \mathrm{mL})$ & $14.36 \pm 0.89^{*}$ & $7.88 \pm 0.67$ \\
\hline $\mathrm{IL}-8(\mathrm{pg} / \mathrm{mL})$ & $3.21 \pm 0.32^{*}$ & $1.82 \pm 0.23$ \\
\hline TNF- $\alpha(\mathrm{ng} / \mathrm{mL})$ & $2.55 \pm 0.12^{*}$ & $0.42 \pm 0.04$ \\
\hline
\end{tabular}

Values are expressed as mean $\pm \mathrm{SEM} ;{ }^{*}$ Means are significantly different at the level $(\mathrm{P} \leq 0.05)$ 
W. M. El-Deeb and S. M. El-Bahr: Novel biomarkers of ketosis in postparturient cows

Table 3. Spearmen's correlation coefficient among traditional (BHBA, NEFA) and suggested (TNF- $\alpha$, IFN- $\gamma$, IL-1 $\beta$, IL-6, IL-12, IL-8) biomarkers of ketosis in cows affected with ketosis

\begin{tabular}{|l|c|c|c|c|c|c|c|}
\hline Variables & $\begin{array}{c}\text { BHBA } \\
(\mathrm{mmol} / \mathrm{L})\end{array}$ & $\begin{array}{c}\text { NEFA } \\
(\mathrm{mg} / \mathrm{dL})\end{array}$ & $\begin{array}{c}\text { TNF- } \alpha \\
(\mu \mathrm{g} / \mathrm{L})\end{array}$ & $\begin{array}{c}\text { IFN- } \gamma \\
(\mathrm{pg} / \mathrm{ml})\end{array}$ & $\begin{array}{c}\text { IL-1 } \beta \\
(\mathrm{pg} / \mathrm{ml})\end{array}$ & $\begin{array}{c}\text { IL-6 } \\
(\mathrm{ng} / \mathrm{ml})\end{array}$ & $\begin{array}{c}\text { IL-12 } \\
(\mathrm{ng} / \mathrm{ml})\end{array}$ \\
\hline BHBA $(\mathrm{mmol} / \mathrm{L})$ & & & & & & & \\
\hline NEFA $(\mathrm{mg} / \mathrm{dL})$ & $0.974 * * *$ & & & & & & \\
\hline TNF- $\alpha(\mu \mathrm{g} / \mathrm{L})$ & $0.935^{* * *}$ & $0.960^{* * *}$ & & & & & \\
\hline IFN- $\gamma(\mathrm{pg} / \mathrm{mL})$ & $0.963^{* * *}$ & $0.966^{* * *}$ & $0.948^{* * *}$ & & & & \\
\hline IL-1 $\beta(\mathrm{pg} / \mathrm{mL})$ & $0.964^{* * *}$ & $0.980^{* * *}$ & $0.948^{* * *}$ & $0.975^{* * *}$ & & & \\
\hline IL-6 $(\mathrm{ng} / \mathrm{mL})$ & $0.294^{*}$ & $0.296^{*}$ & $0.370^{*}$ & $0.307 *$ & $0.335^{*}$ & & \\
\hline IL-12 $(\mathrm{ng} / \mathrm{mL})$ & $0.904^{* * *}$ & $0.927^{* * *}$ & $0.896^{* * *}$ & $0.935^{* * *}$ & $0.944^{* * *}$ & $0.283^{*}$ & \\
\hline IL-8 $(\mathrm{pg} / \mathrm{mL})$ & $0.860^{* * *}$ & $0.835^{* * *}$ & $0.822^{* * *}$ & $0.869^{* * *}$ & $0.862 * * *$ & $0.429 * *$ & $0.836^{* * *}$ \\
\hline
\end{tabular}

BHBA: beta hydroxyl butyric acids; NEFA: Non esterified free fatty acids; TNF- $\alpha$ : Tumor necrosis factor $\alpha$; IFN- $\gamma$ : interferon gamma; IL-1 $\beta$ : interleukins 1 $\beta$; IL-6: interleukins 6; IL-12: interleukins 12; IL-8: interleukins 8. * Significant correlations at $\mathrm{P}<0.05$; **Significant correlations at $\mathrm{P}<0.01$ and $* *$ Significant correlations at $\mathrm{P}<0.001$.

Table 4. Spearmen's correlation coefficient among traditional (BHBA, NEFA) and suggested (Hp, SAA, $\alpha 1-A G, C p, F b)$ biomarkers of ketosis in cows affected with ketosis

\begin{tabular}{|l|c|c|c|c|c|c|}
\hline Variables & $\begin{array}{c}\text { BHBA } \\
(\mathrm{mmol} / \mathrm{L})\end{array}$ & $\begin{array}{c}\text { NEFA } \\
(\mathrm{mg} / \mathrm{dL})\end{array}$ & $\mathrm{HP}(\mathrm{g} / \mathrm{L})$ & $\begin{array}{c}\text { SAA } \\
(\mathrm{mg} / \mathrm{L})\end{array}$ & $\begin{array}{c}\alpha 1-\mathrm{AG} \\
(\mathrm{g} / \mathrm{L})\end{array}$ & $\mathrm{Cp}(\mathrm{g} / \mathrm{L})$ \\
\hline BHBA $(\mathrm{mmol} / \mathrm{L})$ & & & & & & \\
\hline NEFA $(\mathrm{mg} / \mathrm{dL})$ & $0.974 * * *$ & & & & & \\
\hline $\mathrm{HP}(\mathrm{g} / \mathrm{L})$ & $0.927 * * *$ & $0.969 * * *$ & & & & \\
\hline $\mathrm{SAA}(\mathrm{mg} / \mathrm{L})$ & $0.949 * * *$ & $0.959 * * *$ & $0.942 * * *$ & & & \\
\hline$\alpha 1-\mathrm{AG}(\mathrm{g} / \mathrm{L})$ & $0.714 * *$ & $0.717 * *$ & $0.690 * *$ & $0.739 * *$ & & \\
\hline $\mathrm{Cp}(\mathrm{g} / \mathrm{L})$ & $0.647 * *$ & $0.694 * * *$ & $0.668^{* *}$ & $0.705^{* *}$ & $0.550^{* *}$ & \\
\hline $\mathrm{Fb}(\mathrm{g} / \mathrm{L})$ & $0.198^{*}$ & $0.214^{*}$ & $0.171^{*}$ & $0.197 *$ & $0.037 *$ & $0.060 *$ \\
\hline
\end{tabular}

BHBA: beta hydroxyl butyric acids; NEFA: Non esterified free fatty acids; Hp: Haptoglobin; SAA: serum amyloid A; $\alpha 1-A G$ : $\alpha 1$ Acid glycoprotein; Cp: Ceruloplasmin; Fb: Fibrinogen; *Significant correlations at $\mathrm{P}<0.05$; ** Significant correlations at $\mathrm{P}<0.01$ and $* * *$ Significant correlations at $\mathrm{P}<0.001$.

The correlation between traditional (BHBA, NEFA) and suggested (acute phase proteins and proinflammatory cytokines) biomarkers of ketosis in cows affected with ketosis. The data summarized in Table 3 indicated that, $\beta$-Hydroxybutyrate (BHBA) was positively correlated with non-esterified fatty acids (NEFA) $(r=0.974 ; \mathrm{p}=0.000)$. Further, both $\beta$-Hydroxybutyrate BHBA and non-esterified fatty acids (NEFA) were positively correlated with tumor necrosis alpha $(\mathrm{TNF}-\alpha)(\mathrm{r}=0.935 ; 0.960)$, interferon gamma $($ IFN- $\gamma)(\mathrm{r}=0.963 ; 0.966)$, and all interleukins: IL-1 $\beta(\mathrm{r}=0.964 ; 0.980)$, IL6 $(\mathrm{r}=$ 0.294; 0.296), IL12 ( $\mathrm{r}=0.904 ; 0.927)$ and IL8 $(\mathrm{r}=0.860 ; 0.835)$. The data summarized in Table 4 indicated that both $\beta$-Hydroxybutyrate (BHBA) and non-esterified fatty acids 
(NEFA) were positively correlated with haptoglobin $(\mathrm{Hp})(\mathrm{r}=0.927 ; 0.969)$, serum amyloid A (SAA) $(\mathrm{r}=0.949 ; 0.959)$, alpha-1 acid glycoprotein $(\alpha 1-\mathrm{AG})(\mathrm{r}=0.714$; 0.717), fibrinogen $(\mathrm{Fb})(\mathrm{r}=0.198 ; 0.214)$ and ceruloplasmin $(\mathrm{Cp})(\mathrm{r}=0.647 ; 0.694)$.

\section{Discussion}

The clinical signs observed in cows affected with ketosis in the current study are in accordance with those obtained earlier in cows (TÓTHOVÁ et al., 2014) and buffaloes (GHANEM and EL-DEEB, 2010; YOUSSEF et al., 2010). Beside the clinical signs observed in ketotic cows in the current study, ketosis was proven by a positive test for ketone bodies in the urine, ketonuria. In addition, the significant increase of non-esterified fatty acids (NEFA) and $\beta$-Hydroxybutyrate BHBA in the serum of ketotic cows in the postparturient period confirmed the observed clinical findings. Although many studies (KEHRLI et al., 1989; GILBERT et al., 1993; MALLARD et al., 1998; KIM et al., 2005) have reported the role of the reduced functioning of neutrophils and lymphocytes in the postparturient period and the subsequent high susceptibility to infectious disease, data regarding their association with ketosis have not been completely elucidated. Therefore, the current study suggests proinflammatory cytokines and acute phase proteins as prognostic and diagnostic biomarkers of ketosis in this period. The use of acute phase proteins to monitor reproductive disorders (KRAKOWSKI and ZDZISINSKA, 2007) and ketosis (FATHI et al., 2013 ) in cows has already been documented. Disturbances in homeostasis in the transition period are the animal's reaction, known as the acute phase response (PINEIRO et al., 2003). Changing concentrations in acute phase proteins (APP) is the most striking phenomenon (PETERSEN et al., 2004). Haptoglobin (Hp) and serum amyloid A (SAA) are the most important acute phase proteins (APP) in cattle (KRAKOWSKI and ZDZISINSKA, 2007; PAULINA and TADEUSZ, 2011). They play an important role in the reconstitution of tissues damaged during inflammation (REGASSA and NOAKES, 1999). The significant elevation of Haptoglobin (Hp) and serum amyloid A (SAA) concentrations in the serum of ketotic cows in the current study compared to the control has been reported earlier in cows around (GYMNICH et al., 2003; TÓTHOVÁ et al., 2014) and after (AMETAJ, 2005; CHAN et al., 2010) delivery. The significant positive correlation between both $\beta$-Hydroxybutyrate (BHBA) and non-esterified fatty acids (NEFA) with acute phase proteins (APP) is in accordance with the findings of a previous report (HARDARDOTTIR et al., 1994). The current findings comply with these findings as a significant increase in Haptoglobin $(\mathrm{Hp})$, serum amyloid A (SAA), fibrinogen $(\mathrm{Fb})$, ceruloplasmin $(\mathrm{Cp})$ and $1 \alpha$-glycoprotein $(1 \alpha-$ AG) was observed in ketotic cows compared to the control in the postparturient period. The significant increase in proinflammatory cytokines levels (IL-1 $\alpha$, IL-1 $\beta$, IL-6, IL-8, IL-12, TNF- $\alpha$ and IFN- $\gamma$ ) in ketotic cows compared to the control animals, as reported in the current study, is in accordance with previous reports in cows (JONSSON et al., 2013; TREVISI et al., 2015). In addition, plasma interleukins were positively correlated with the severity of the inflammation (TREVISI et al., 2015). Higher levels of proinflammtory 
cytokines (IL, TNF- $\alpha$, IFN- $\gamma$ ), perhaps released as a result of high NEFA, were observed in the serum of ketotic cows in the current study (DYK et al., 1995; SORDILLO et al., 2009). This suggestion is confirmed by the significant correlation observed among both the traditional biomarkers of ketosis ( $\beta$-Hydroxybutyrate (BHBA) and non-esterified fatty acids (NEFA)) and cytokines in the serum of the cows affected with ketosis in the present study. Based on the results presented in Table 3 and Table 4, it may be said that $\beta$-Hydroxybutyrate (BHBA) and non-esterified fatty acids (NEFA) were positively correlated with acute phase responses and cytokine release in cows affected with ketosis. The current study may conclude that in the postpaturient period in cows, lipid mobilization and fatty acid oxidation increased with the subsequent increase in ketone bodies $\beta$-Hydroxybutyrate (BHBA), creating a state of inflammation. As a result of that inflammation, proinflammatory cytokines may release and stimulate the release of acute phase proteins (Haptoglobin, Serum amyloid A, fibrinogen, ceruoloplasmin and $\alpha 1$-acid glycoprotein) from macrophages or other organs. Acute phase proteins may reconstitute the damaged inflamed tissues. Therefore, acute phase proteins (APP) and proinflammatory cytokines could be used as promising biomarkers for ketosis in dairy cows in the postparturient period. In addition, anti-inflammatory therapy may useful in the treatment of ketosis in cows in the postparturient period.

\section{References}

AMETAJ, B. (2005): A new understanding of the causes of fatty liver in dairy cows. Adv. Dairy Technol. 17, 97-112.

BERTONI, G., E. TREVISI (2013): Use of the liver activity index and other metabolic variables in the assessment of metabolic health in dairy herds. Vet. Clin. N. Am. 29, 413-431.

CHAN, J. P. W., C. C. CHANG, W. I. HSU, W. B. LIU, T. H. CHEN (2010): Association of increased serum acute-phase protein concentrations with reproductive performance in dairy cows with postpartum metritis. Vet. Clin. Pathol. 39, 72-78.

CONTRERAS, G. A., L. M. SORDILLO (2011): Lipid mobilization and inflammatory responses during the transition period of dairy cows. Comp. Immunol. Microbiol. Infect. Dis. 34, 281289.

DRACKLEY, J. K., H. M. DANN, G. N. DOUGLAS, N. A. J. GURETZKY, N. B. LITHERLAND, J. P. UNDERWOOD, J. J. LOOR (2005): Physiological and pathological adaptations in dairy cows that may increase susceptibility to periparturient diseases and disorders. Ital. J. Anim. Sci. 4, 323-344.

DYK, P. B., R. S. EMERY, J. L. LIESMAN, H. F. BUCHOLTZ, M. J. VANDEHAAR (1995): Peripartum non-esterified fatty acids in plasma are higher in cows developing periparturient health problems. J. Dairy Sci. 78, 264-268.

EL-BAHR, S. M., W. M. EL-DEEB(2013): Acute phase proteins, lipid profile and proinflammatory cytokines in healthy and bronchopneumonic water buffalo calves. Am. J. Biochem. Biotechnol. 9, 34-40. 
EL-DEEB, W., S. M. EL-BAHR (2014a): Selected biochemical indicators of equine rhabdomyolysis in Arabian Horses: acute phase proteins and trace elements. J. Equine Vet. Sci. 34, 484-488.

EL-DEEB, W., S. M. EL-BAHR (2014b): Acute phase proteins and oxidative stress biomarkers in water buffalo calves subjected to transportation stress. Clin. Comp. Pathol. 23, 577-582.

EL-DEEB, W. M., S. M. EL-BAHR (2010): Investigation of selected biochemical indicators of Equine Rhabdomyolysis in Arabian horses: pro-inflammatory cytokines and oxidative stress markers. Vet. Res. Commun. 34, 677-689

EL-DEEB, W. M., T. A. FOUDA, S. M. EL-BAHR (2014): Clinico-biochemical investigation of paratuberculosis of dromedary camels in Saudi Arabia: proinflammatory cytokines, acute phase proteins and oxidative stress biomarkers. Pak. Vet. J. 34, 484-488.

FATHI, E., H. HAMALI, M. T. KALEIBAR (2013): Application of acute phase proteins as indicators of ketosis and their relation to energy metabolites in post-calving dairy cows. Int. J. Rec. Sci. Res. 4, 842-845.

GABAY, C., I. KUSHNER (1999): Acute-phase proteins and other systemic responses to inflammation. N. Engl. J. Med. 340, 448-454.

GHANEM, M. M., W. M EL-DEEB (2010): Lecithin cholesterol acyltransferase (LCAT) activity as a predictor for ketosis and parturient haemoglobinuria in Egyptian water buffaloes. Res. Vet. Sci. 88, 20-25.

GILBERT, R. O., Y. T. GROHN, P. M. MILLER, D. J. HOFFMAN (1993): Effect of parity on periparturient neutrophil function in dairy cows. Vet. Immunol. Immunopathol. 36, 75-82.

GOFF, J. P., R. L. HORST (1997): Physiological changes at parturition and their relationship to metabolic disorders. J. Dairy Sci. 80, 1260-1268.

GONZALEZ, F. D., R. MUINO, V. PEREIRA, R. CAMPOS, J.L. BENEDITO (2011): Relationship among blood indicators of lipomobilization and hepatic function during early lactation in highyielding dairy cows. J. Vet. Sci. 12, 251-255.

GRUYS, E., M. J. M. TOUSSAINT, T. A. NIEWOLD, S. J. KOOPMANS (2005): Acute phase reaction and acute phase proteins. J. Zhejiang Univ. Sci. B. 6, 1045-1056.

GYMNICH, S., S. HISS, H. SAUERWEIN, B. PETERSEN (2003): Haptoglobin in sows at parturition. In: Proceedings of the Fourth European Colloquium on Acute Phase Proteins, Segovia, Spain, 136.

HARDARDOTTIR, I., C. GRUNFELD, K.R. FEINGOLD (1994): Effects of endotoxin and cytokines on lipid metabolism. Curr. Opin. Lipidol. 5, 207-215.

ISHIKAWA, Y., K. NAKADA, K. HAGIWARA, R. KIRISAWA, H. IWAI, M. MORIYOSHI, Y. SAWAMUKAI (2004): Changes in interleukin- 6 concentration in peripheral blood of pre- and post-partum dairy cattle and its relationship to postpartum reproductive diseases. J. Vet. Med. Sci. 66, 1403-1408.

ISLAM, R., H. KUMAR, S. NANDI, S. MEHROTRA (2013a): Circulatory level of interleukin-1 in periparturient cows with or without postpartum reproductive diseases. Asian Pacific J. Reprod. 2, 316-320.

ISLAM, R., H. KUMAR, S. NANDI, R. B. RAI (2013b): Determination of anti-inflammatory cytokine in periparturient cows for prediction of postpartum reproductive diseases. Theriogenology 79, 974-979. 
JONSSON, N. N., M. R. S. FORTES, E. K. PIPER, D. M. VANKAN, J. P. J. DE CISNEROS, T. WITTEK (2013): Comparison of metabolic, hematological, and peripheral blood leukocyte cytokine profiles of dairy cows and heifers during the periparturient period. J. Dairy Sci. 96, 2283-2292.

JORRITSMA, R., H. JORRITSMA, Y. H. SCHUKKEN, P. C. BARTLETT, T. WENSING, G. H. WENTINK (2001): Prevalence and indicators of postpartum fatty infiltration of the liver in nine commercial dairy herds in The Netherlands. Livest. Prod. Sci. 68, 53-60.

KEHRLI, M. E., B. J. NONNECKE, J. A. ROTH (1989): Alterations in bovine lymphocyte function during the periparturient period. Am. J. Vet. Res. 50, 215-220.

KIM, I. H., K. J. NA, M. P. YANG (2005): Immune responses during the peripartum period in dairy cows with postpartum endometritis. J. Reprod. Dev. 51, 757-764.

KOJ, A. (1998): Termination of acute-phase response: role of some cytokines and antiinflammatory drugs. Gen. Pharmacol. 31, 9-18.

KRAKOWSKI, L., B. ZDZISIŃSKA (2007): Selected cytokines and acute phase proteins in heifers during the ovarian cycle course and in different pregnancy periods. Bull. Vet. Inst. Pulawy. 51, 31-36.

KUSHIBIKI, S. (2011): Tumor necrosis factor- $\alpha$ - induced inflammatory responses in cattle. Anim. Sci. J. 82, 504-511.

LOUGHMILLER, J. A., S. S. DRITZ, J. L. NELSSEN, M. D. TOKACH, R. D. GOODBAND, S. A. MOSER, M. DE LA LLATA (2007): Effects of salmonella typhimurium challenge on swine growth, nitrogen balance, insulin-like growth factor-i and acute phase proteins. Am. J. Anim. Vet. Sci. 2, 11-22.

MALLARD, B. A., J. C. DEKKERS, M. J. IRELAND, K. E. LESLIE, S. SHARIF, C. L. VANKAMPEN, L. WAGTER, B. N. WILKIE (1998): Alteration in immune responsiveness during the peripartum period and its ramification on dairy cow and calf health. J. Dairy Sci. 81, 585-595.

MELENDEZ, P., M. P. MARIN, J. ROBLES, C. RIOS, M. DUCHENS, L. ARCHBALD (2009): Relationship between serum nonesterified fatty acids at calving and the incidence of periparturient diseases in Holstein dairy cows. Theriogenology 72, 826-833.

PAULINA, J., S. TADEUSZ (2011): Acute phase proteins in cattle. In: Acute Phase Proteins as early Nonspecific Biomarkers of Human and Veterinary Diseases. (Veas, F., Ed.), In Tech Europe, Rijeka, pp. 381-408.

PETERSEN, H. H., J. P. NIELSEN, P. M. H. HEEGAARD (2004): Application of acute phase protein measurements in veterinary clinical chemistry. Vet. Res. 35, 163-187.

PINEIRO, M., M. A. ALAVA, F. LAMPREAVE (2003): Acute phase proteins in different species: A review. Fourth European Colloquium on Acute Phase Proteins, Segovia, Spain, pp. 77-82.

RADOSTITS, O. M., C. C. GAY, K. W. HINCHCLIFF, P. D. CONSTABLE (2007): Veterinary Medicine: A Textbook of the Diseases of Cattle, Horses, Sheep, Pigs and Goats. A $10^{\text {th }}$ ed., Elsevier Health Sciences, Philadelphia, PA, USA.

REGASSA, F., D. E. NOAKES (1999): Acute phase protein response of ewes and the release of PGFM in relation to uterine involution and the presence of intrauterine bacteria. Vet. Rec. 144, 502-506. 
W. M. El-Deeb and S. M. El-Bahr: Novel biomarkers of ketosis in postparturient cows

SAS (2002): Statistical Analysis System. User's Guide. SAS Institute Inc., Cary, NC, USA.

SORDILLO, L. M., G. A. CONTRERAS, S. L. AITKEN (2009): Metabolic factors affecting the inflammatory response of periparturient dairy cows. Anim. Health Res. Rev. 10, 53-63.

TÓTHOVÁ, C., O. NAGY, G. KOVÁC (2014): Changes in the concentrations of selected acute phase proteins and variables of energetic profile in dairy cows after parturition. J. Appl. Anim. Sci. 42, 278-283.

TREVISI, E., M. AMADORI, S. COGROSSI, E. RAZZUOLI, G. BERTONI (2012): Metabolic stress and inflammatory response in high-yielding, periparturient dairy cows. Res. Vet. Sci. 93, 695-704.

TREVISI, E., N. JAHAN, G. BERTONI, A. FERRARI, A. MINUTI (2015): Pro-inflammatory cytokine profile in dairy cows: consequences for new lactation. Ital. J. Anim. Sci. 14, 285-292.

YAQOOB, P., P. C. CALDER (2007): Fatty acids and immune functions: new insights into mechanisms. Br. J. Nutr. 98, 41-45.

YOUSSEF, M. A., S. A. EL-KHODERY, W. M. EL-DEEB, W. E. E. ABOU EL-AMAIEM (2010): Ketosis in buffalo (Bubalus bubalis): clinical findings and the associated oxidative stress level. Trop. Anim. Health Prod. 42, 1771-1777.

ZHANG, W. Y., E. SCHWARTZ, Y. WANG, J. ATTREP, Z. LI, P. REAVEN (2006): Elevated concentrations of nonesterified fatty acids increase monocyte expression of CD11b and adhesion to endothelial cells. Arterioscler. Thromb. Vasc. Biol. 26, 514-519.

Received: 26 January 2016

Accepted: 22 November 2016

\section{EL-DEEB, W. M., S. M. EL-BAHR: Biomarkeri ketoze u mliječnih krava u postpartalnom razdoblju: proteini akutne faze i proupalni citokini. Vet. arhiv 87, 431-440, 2017. \\ SAŽETAK}

Pronalaženje novih ili dodatnih biomarkera bitni je korak u kontroli metaboličkih bolesti kao što je ketoza. Proteini akutne faze i proupalni citokini uspješno se koriste kao prognostički i dijagnostički biomarkeri za mnoge životinjske bolesti. Ipak, njihova primjena u dijagnostici ketoze u mliječnih krava u postpartalnom razdoblju nije u potpunosti razjašnjena. Stoga je u ovo istraživanje bilo uzeto 25 krava oboljelih od ketoze u postpartalnom razdoblju, zajedno s 20 zdravih kontrolnih krava. Uzorci krvi bili su prikupljeni od bolesnih i zdravih životinja te su uzorci seruma bili pretraženi na proteine akutne faze i proupalne citokine. Dobiveni rezultati pokazali su da se $\mathrm{u}$ krava s ketozom u odnosu na kontrolnu skupinu značajno $(\mathrm{P} \leq 0,05)$ povećala razina $\beta$-hidroksibutirata (BHBA), neesterificiranih masnih kiselina (NEMK), proteina akutne faze $i$ to haptoglobina (HP), serumskog amiloida A (SAA), fibrinogena ( $\mathrm{Fb})$, ceruloplazmina (Cp), $\alpha 1$-kiselog glikoproteina ( $\alpha 1-\mathrm{AG})$ i proupalnih citokina kao što su interleukini (IL-1 $\beta$, IL-6, IL-8, IL-12), faktor tumorske nekroze alfa (TNF- $\alpha$ ) i interferon gama (IFN- $\gamma$ ). Pozitivna korelacija utvrđena je između postojećih biomarkera (BHBA, NEMK) i novih predloženih na osnovi ovog istraživanja (proteina akutne faze i citokina) u krava oboljelih od ketoze. Zaključuje se da bi proteini akutne faze i proupalni citokini mogli biti obećavajući biomarkeri ketoze u krava u postpartalnom razdoblju.

Ključne riječi: krave, ketoza, haptoglobin, fibrinogen, serumski amiloid A, citokini 